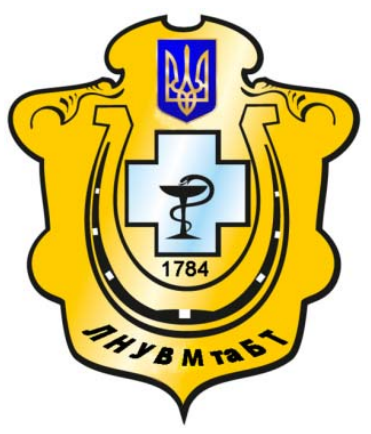

Науковий вісник Львівського національного університету ветеринарної медицини та біотехнологій імені С.3. Гжицького

Scientific Messenger of Lviv National University of Veterinary Medicine and Biotechnologies named after S.Z. Gzhytskyj

doi:10.15421/nvlvet7144

ISSN 2413-5550 print

ISSN $2518-1327$ online

$\underline{\text { http://nvlvet.com.ua/ }}$

УДК637; 577.15

\title{
Лабораторна характеристика рідкого ензимного мийного засобу «Ензимий» для санобробки у молочній промисловості
}

\author{
О.Ю. Шинкарук \\ oksanka_schynkaruk@mail.ru
}

Тернопільський національний технічний університет імені Івана Пулюя, вул. Руська, 56, Тернопіль, Тернопільська область, 46001, Україна

\begin{abstract}
Нами було розроблено рідкий ензимний мийний засіб «Ензимий» для санітарної обробки СІР-установок на молочних підприємствах, у склад якого входять: калію гідроксид, комплексони, протеолітичний ензим, стабілізатори, вода дистильована. Попередні лабораторні дослідження встановили, щя найвища активність «Ензимию» щодо молочних білків спостерігалася за температури $60^{\circ} \mathrm{C}$ і становила 65,8\%. 3 підвищенням температури вище $60^{\circ} \mathrm{C}$ активність знижується, у зв'язку з тим, щьо ензими денатуруються, адже висока температура призводить до змін у первинній структурі $i$ конформачії ензиму. Також виявлено, щуо за рН розчинів 8,35 од. протеолітична активність зросла у 1,7 раза $(P \leq 0,01)$, порівняно з рН 7,2 од. і досягла своєї максимальної активності 65,8-64\%. Подальше збільшення рН розчинів від 8,35 од. до 8,6 од. сприяло поступовому інгібуванню ензимів, внаслідок чого протеолітична активність знижувалася до 0. Протеолітична активність дослідного варіанту ензимного мийного засобу за твердості води 0,357 мг-екв/л також досягала максимуму і становила 60,5\%, а при збільшенні твердості води від 0,714 до 1,071 мг-екв/л ПА знижувалася на 25,4\% (P $\leq 0,05)$, тобто зі збільшенням твердості води ПА відповідно знижусться.

В статті представлено результати досліджень піноутворювальної здатності, стійкості піни та поверхневого натягу розчинів. Для проведення досліджень використовували рідкий ензимний мийний засіб «Ензимий» у концентраціях 0,03; 0,05; 0,07; 0,1; 0,3; 0,5; 0,7; $1 \%$ за температури $20^{\circ} \mathrm{C}$ і $60^{\circ} \mathrm{C}$. За результатами даних досліджень встановлено, щоо «Ензимий» практично не проявляє піноутворювальної здатності у конщентрації від 0,03 до 1\%. Стійкість піни не перевищує норматив - не більше 50 \% об'єму розчину через 5 хв., щзо дозволяє використовувати розроблену рецептуру для безрозбірного ичикуляційного миття технологічного обладнання молокопереробних підприємств.
\end{abstract}

Ключові слова: СІР-системи, ензимний мийний засіб, мікробні біоплівки, піноутворювальна здатність, стійкість піни, поверхневий натяг, миття, кониентрація, температура, ПАР.

\section{Лабораторная характеристика жидкого энзимного моющего средства «Ензимий» для санобработки в молочной промышленности}

\author{
О.Ю. Шинкарук \\ oksanka_schynkaruk@mail.ru
}

Тернопольский национальный технический университет имени Ивана Пулюя, ул. Русская, 56, Тернополь, Тернопольская область, 46001, Украина

\begin{abstract}
Нами было разработано жидкое энзимное моющее средство «Ензимий» для санитарной обработки СІР-установок на молочних предприятиях, в состав котрого входят: гідроксид калия, комплексоны, протеолитический энзим, стабилизатоpы, вода дистиллированная. Предварительные лабораторные исследования установили, что самая высокая активность «Ензимию» в отночении молочных белков наблюдалась при температуре $60{ }^{\circ} \mathrm{C}$ и составляла 65,8\%. C повымением температуры выше $60^{\circ} \mathrm{C}$ активность снижается, в связи с тем, что денатурируются энзимы, ведь высокая температура приводит к изменениям в первичной структуре и конформачии энзима. Также обнаружено, что при рН растворов 8,35 ед. протеолитическая активность возросла в 1,7 раза $(P \leq 0,01)$, по сравнению с рН 7,2 ед. и достигла своей максимальной
\end{abstract}

Citation:

Shynkaruk, O.Y. (2016). Laboratory characteristics of liquid enzyme detergent «Enzymyi» for sanitation in dairy industry. Scientific Messenger LNUVMBT named after S.Z. Gzhytskyj, 18, 3(71), 195-200. 
активности 65,8 - 64\%. Дальнейшее увеличение рН растворов от 8,35 ед. до 8,6 ед. способствовало постепенному ингибированию энзимов, вследствие чего протеолитическая активность снижалась до 0. Протеолитическая активность исследовательского варианта энзимного моющего средства при жесткости воды 0,357 мг-экв/л также достигала максимума и


увеличением жесткости воды ПА соответственно снижается.

В статье представлены результаты исследований пенообразовательной способности, устойчивости пень и поверхностного натяжения растворов. Для проведения исследований использовали жидкое энзимное моющее средство «Ензимий» в концентрациях 0,03; 0,05; 0,07; 0,1;0,3;0,5;0,7;1\% при температуре $20^{\circ} \mathrm{C}$ i $60^{\circ} \mathrm{C}$.

По результатам даннях исследований установлено, что «Ензимий» практически не проявляет пенообразовательной способности в концентрации от 0,03 до 1\%. Устойчивость пень не превыпает норматив - не более $50 \%$ объема раствора через 5 мин., что позволяет использовать разработанную рецептуру для безразборного ичиркуляционного мытья технологического оборудования молокоперерабатьвающих предприятий.

Ключевые слова: СИР-системы, энзимное моющее средство, микробные биопленки, пенообразовательная способность, устойчивость пень, поверхностное натяжение, мойка, концентрачия, температура, ПАВ.

\title{
Laboratory characteristics of liquid enzyme detergent «Enzymyi» for sanitation in dairy industry
}

\author{
O.Y. Shynkaruk \\ oksanka_schynkaruk@mail.ru \\ Ivan Puluj Ternopil National Technical University, \\ Ruska Str., 56, Ternopil, 46001, Ukraine
}

\begin{abstract}
We have developed a liquid enzyme detergent «Enzymyi» for sanitization of CIP-installations on milk plants that includes potassium hydroxide, complexones, proteolytic enzyme, stabilizers, and distilled water.

The previous laboratory studies showed that the peak activity of "Enzymyi» on milk proteins was observed at as high as $65.8 \%$ at $60^{\circ} \mathrm{C}$. Its activity decrease with the rise of temperature above $60^{\circ} \mathrm{C}$ due to denaturation of enzymes since the heat causes changes in the primary structure and conformation of enzyme. It is also established that at pH solutions of 8.35 units proteolytic activity increased 1.7 times $(P \leq 0.01)$ compared to $7.2 \mathrm{pH}$ units and reached its maximum activity $65.8-64 \%$. Further increase of $p H$ solutions from 8.35 units to 8.6 units contributed to gradual inhibition of enzymes resulting in reduction of proteolytic activity to 0. Proteolytic activity of the studied sample of enzyme detergent at water hardness of $0.357 \mathrm{mg}-\mathrm{eq} / \mathrm{l}$ also reached the maximum of $60.5 \%$ and at increasing water hardness from 0.714 to $1.071 \mathrm{mg}-$ eq/l PA decreased by $25.4 \%(P \leq 0,05)$, i.e. with increasing water hardness $P A$ reduced respectively. The article presents the study results as regards foam generating ability, foam stability and surface tension of solutions. The liquid detergent enzyme "Enzymyi» in concentrations of $0.03 ; 0.05 ; 0.07 ; 0.1 ; 0.3 ; 0.5 ; 0.7 ; 1 \%$ at the temperatures $20^{\circ} \mathrm{C}$ and $60^{\circ} \mathrm{C}$ was used for study. The article presents the study results as regards foam generating ability, foam stability and surface tension of solutions. The liquid detergent enzyme «Enzymyi» in concentrations of 0.03; 0.05; 0.07; 0.1; 0.3; 0.5; 0.7; $1 \%$ at the temperatures $20^{\circ} \mathrm{C}$ and $60^{\circ} \mathrm{C}$ was used for study.

The results showed that "Enzymyi» practically doesn't develop foam generating ability at the concentration from 0.03 to $1 \%$. Foam stability does not exceed the standard, thus no more than 50\% of the solution in 5 minutes that allows using the available composition for circulation washing of dairy equipment without its dismounting.

Key words: CIP systems, enzyme detergent, microbial biofilms, foam generating ability, foam stability, surface tension, washing, concentration, temperature, PAR.
\end{abstract}

\section{Вступ}

Необхідною умовою підвищення якості та безпечності молочної продукції $\epsilon$ реалізація на підприємствах молочної промисловості комплексу санітарно-гігієнічних заходів, а саме, використання ефективних мийних та дезінфікуючих засобів одночасно із сучасними передовими технологіями очищення обладнання.

Внаслідок високої уніфікації, модернізації та безперервності технологічних процесів при переробці молока, головним напрямком у забезпеченні ефективного та економічного вирішення проблеми миття технологічного обладнання стало застосування принципу безрозбірної циркуляційної мийки (Clean In Place - CIP-мийки).

Сучасні CIP-системи вирішують увесь комплекс задач повністю автоматично - від нагрівання води і контролю концентрації робочих розчинів до архівації даних про процес миття у кожний проміжок часу.
Перевагами CIP-системи є:

- висока безпечність (до мінімуму зведене ручне обслуговування, відсутній людський фактор);

- якість миття (миттєвий контроль параметрів миття);

- зниження фінансових затрат (економія робочої сили, підвищення продуктивності праці, контроль витрат води, енергії та мийних засобів) (Kyrjutkyn and Molochnykov, 1976).

Важливою умовою мийних засобів, які використовуються у СІР-системах, $є$ їх непінність або низька пінність, так як велика кількість піни може призвести до поломки обладнання. Піни - це грубодисперсні нестійкі системи, що являють собою сукупність бульбашок газу (повітря), розділених тонкими прошарками рідини. При цьому, низькопінний засіб або містить добавку, яка зупиняє піноутворення, - піногасник, або виготовляється на основі комонентів, які не здатні до утворення піни. Для закритих циркуляційних систем миття 
піноутворювальна здатність розчинів засобу не повинна перевищувати $30 \%$, а стійкість піни через 5 хв. не повинна бути більшою $50 \%$.

Змочувальна здатність розчинів засобу залежить від його поверхневого натягу. Чим менший поверхневий натяг, тим краща змочувальна здатність розчину. Поверхневий натяг - сила, яка діє на поверхні рідини і намагається скоротити іiі вільну поверхню до найменшої при сталому об'ємі, а саме до форми кулі. Поверхневий натяг рідини залежить від температури та розчинених у ній речовин i за температури $20{ }^{\circ} \mathrm{C}$ не повинен перевищувати $60 \mathrm{mH} / \mathrm{M}$ (Alagezjan, 1981; Mishhyrjak, 2012).

Таким чином, актуальним питанням при створенні композиції мийного засобу є врахування таких його характеристик, як піноутворювальна здатність, стійкість піни та поверхневий натяг розчинів.

Нині українські і закордонні виробники для санобробки технологічного обладнання молокоперереродбних підприємств випускають, в основному, лужні і кислотні мийні засоби. Білки та жири гідролізуються лугами, а комплекси мінеральних речовин розчиняються та видаляються 3 поверхні обладнання із допомогою кислот (Sergeev, 1989; Degterev and Rekin, 2000).

Результати останніх наукових досліджень вказують, що мікроорганізми виживають на технологічному устаткуванні завдяки надзвичайно важливій властивості - здатності формувати біоплівки. Біоплівка - це жива сукупність одного або декількох видів чи родів бактерій, яка постійно оновлюється, прикріплена до біогенної чи абіогенної поверхні та оточена полісахаридним матриксом. 3 цією метою у країнах західної Свропи набули актуальності засоби із протеолітичними ензимами, які видаляють білково-молочні забруднення на технологічному устаткуванні (Flint et al., 2009; Kuhtyn et al., 2013).

На сьогодні широко використовуються у молочній промисловості вітчизняний «Біомой» та імпортний «Р3-ультрасіл 67».

«Біомой» - ферментний мийний засіб у вигляді порошку, який використовують для миття доїльного обладнання, посуду, автоцистерн на молочних фермах та технологічного обладнання, інвентарю, тари на молокопереробних підприємствах. Неможливість його використання у CIP-системах зумовлена наявністю поверхнево-активної речовини, яка проявляє велику пінність засобу.

«Р3-ультрасіл 67» - нейтральний ферментний рідкий мийний засіб для обробки мембранних фільтраційних установок, а також установок зворотнього осмосу в молочній промисловості, особливо для миючого фільтраційного обладнання, що використовується для збору сироватки, обробки молока та виготовлення сиру.

Нами було розроблено рідкий ензимний мийний засіб «Ензимий» для санітарної обробки СIPустановок на молочних підприємствах, у склад якого входять: калію гідроксид, комплексони, протеолітичний ензим, стабілізатори, вода дистильована.

Метою роботи було визначити піноутворювальну здатність, стійкість піни та поверхневий натяг розчинів дослідного рідкого ензимного мийного засобу «Ензимий» для використання його у СІРустановках.

\section{Матеріал і методи досліджень}

Експериментальні дослідження проводили у лабораторіях Тернопільського національного технічного університету імені Івана Пулюя.

Контролювання піноутворювальної здатності та стійкості піни проводили згідно ДСТУ ISO 696:2005 «Визначення піноуторювальної здатності модифікованим методом Росс-Майлса».

Поверхневий натяг розчинів визначализгідно ДСТУ ISO 304:2007 за допомогою сталагмометра.

\section{Результати та їх обговорення}

Для проведення досліджень використовували рідкий ензимний мийний засіб «Ензимий» у концентраціях 0,$03 ; 0,05 ; 0,07 ; 0,1 ; 0,3 ; 0,5 ; 0,7 ; 1 \%$ за температури $20{ }^{\circ} \mathrm{C}$ і $60{ }^{\circ} \mathrm{C}$ і мийний засіб «Біомой» у концентраціях 0,15 ; 0,3 і 0,5\% за температури $45^{\circ} \mathrm{C}$, згідно з інструкцією до використання.

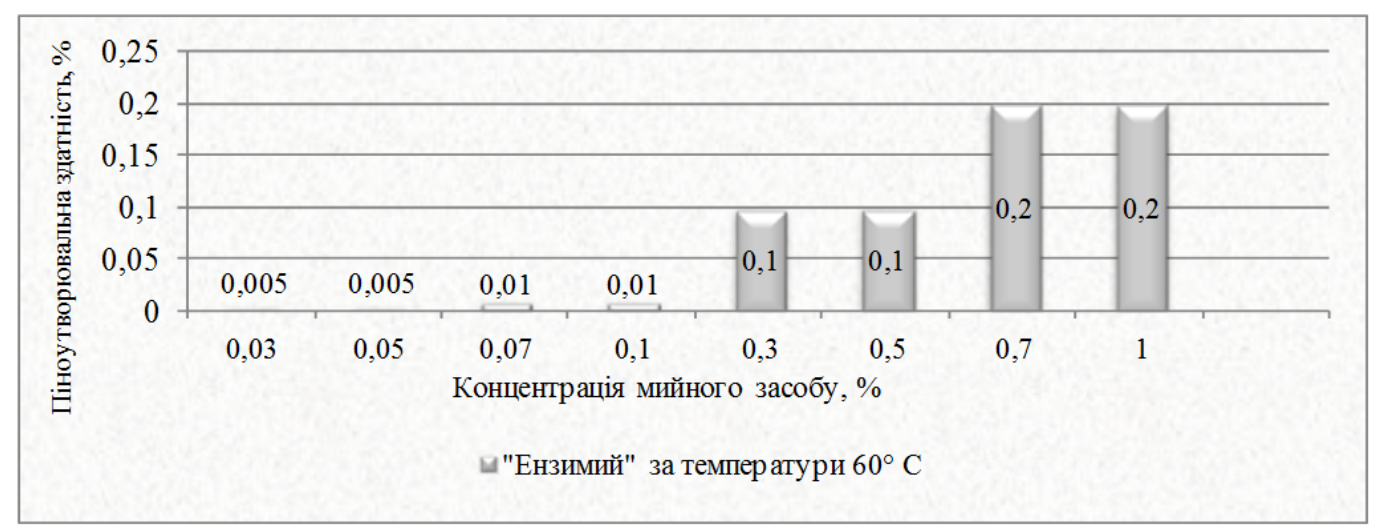

Рис.1. Піноутворювальна здатність рідкого ензимного мийного засобу «Ензимий» за температури $60{ }^{\circ} \mathrm{C}$ 
Дослідження створеного рідкого ензимного мийного засобу «Ензимий» показали (рис. 1), що в інтервалі концентрацій від 0,03 до $1 \%$ розчини практично не проявляють піноутворювальної здатності, що пояснюється відсутністю компонентів, які здатні утворювати піну і дає підставу вважати його перспективним для СІР-установок.

Як видно, із рис. 2 за концентрації «Біомою» $0,15 \%$ піноутворювальна здатність складає 41,2\%. При збільшенні концентрації до 0,3\% піноутворювальна здатність збільшується у 1,5 раза $(\mathrm{P} \leq 0,05)$, а при концентрації $0,5 \%$ - у 1,8 раза $(\mathrm{P} \leq 0,05)$, порівняно із концентрацією $0,15 \%$, і становить $77,29 \%$.

Отже, отримані дані вказують, що піноутворювальна здатність розчинів «Біомою», згідно з інструкцією використання, перевищує нормоване значення, яке, згідно літературних джерел, повинно бути менше $30 \%$. Це пояснюється наявністю у мийному засобі аніонної поверхнево-активної речовини - сульфанолу, яка спричиняє велику пінність, що є не допустимим при використанні його у безрозбірних закритих системах миття, так як піна перешкоджає миттю i здатна виводити з дії установку.

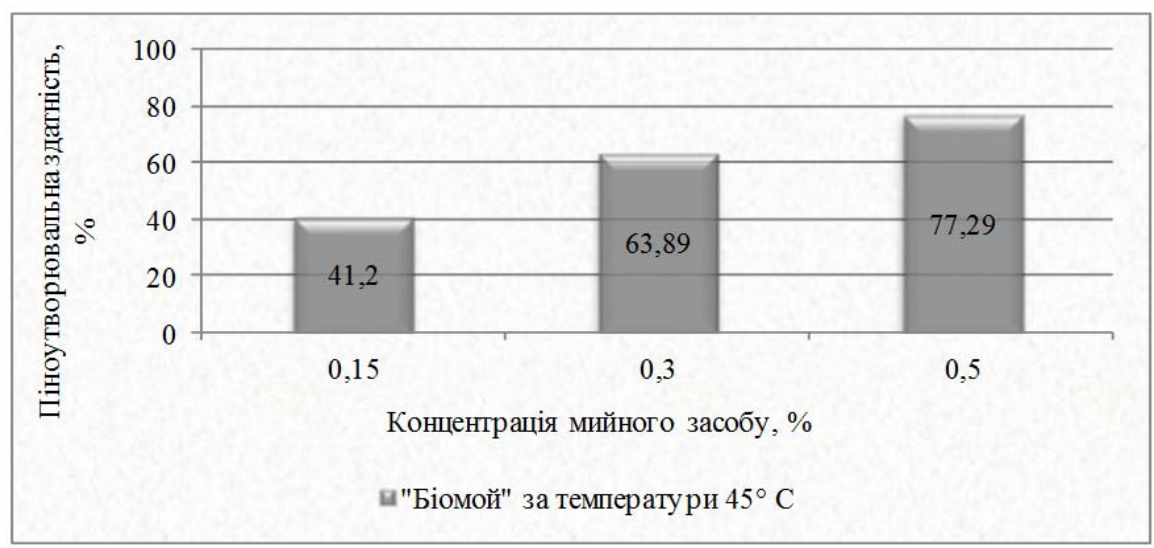

Рис. 2. Піноутворювальна здатність мийного засобу «Біомой» за температури $45^{\circ} \mathrm{C}$

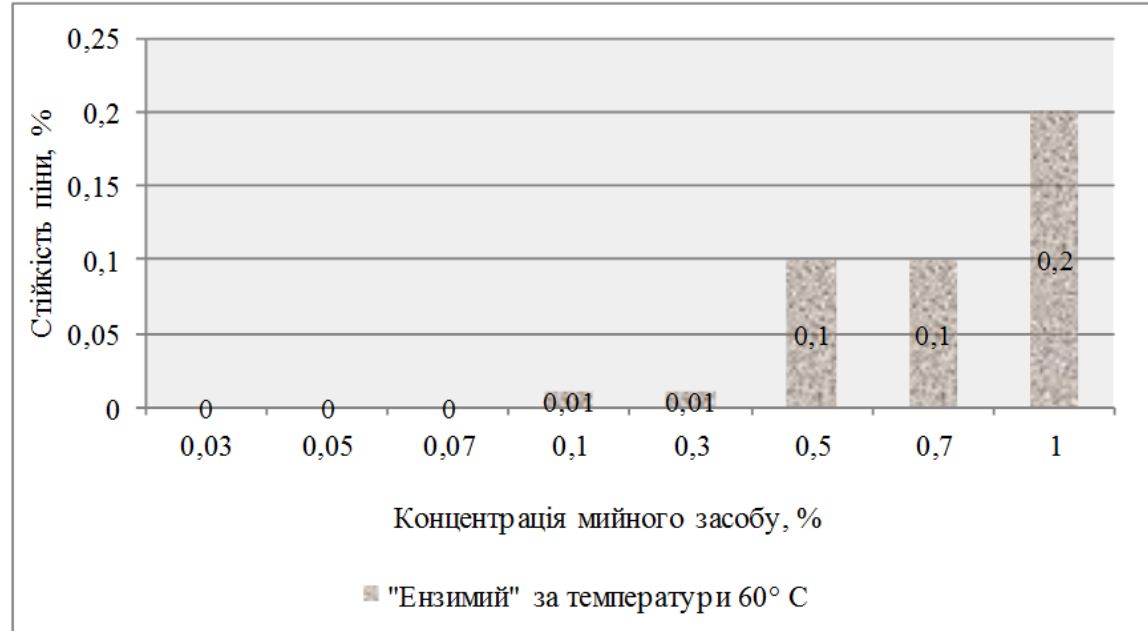

Рис. 3. Стійкість піни рідкого ензимного мийного засобу «Ензимий» за температури $60{ }^{\circ} \mathrm{C}$

Нами було встановлено, що однією і характеристик при виборі мийного засобу для використання у CIP-системах є стійкість піни.

На рис.3 видно, що за концентрації ензимного засобу «Ензимий» $0,03-0,07 \%$ стійкість піни дорівнює нулю. Наступне збільшення концентрації від 0,1 до $0,7 \%$ призводить до збільшення стійкості піни на $0,09 \%$, а при збільшенні до 0,2\% - на 0,19\%, порівняно із концентрацією розчину $0,1 \%$, і становить $0,2 \%$.
Результати проведених досліджень показали, що застосування засобу «Ензимий» при всіх вибраних концентраціях не перевищує нормативну стійкість піни, яка через 5 хв. повинна бути не більше 50\% об'єму розчину, що у свою чергу дозволяє використовувати розроблену рецептуру для безрозбірного циркуляційного миття технологічного обладнання молокопереробних підприємств. 


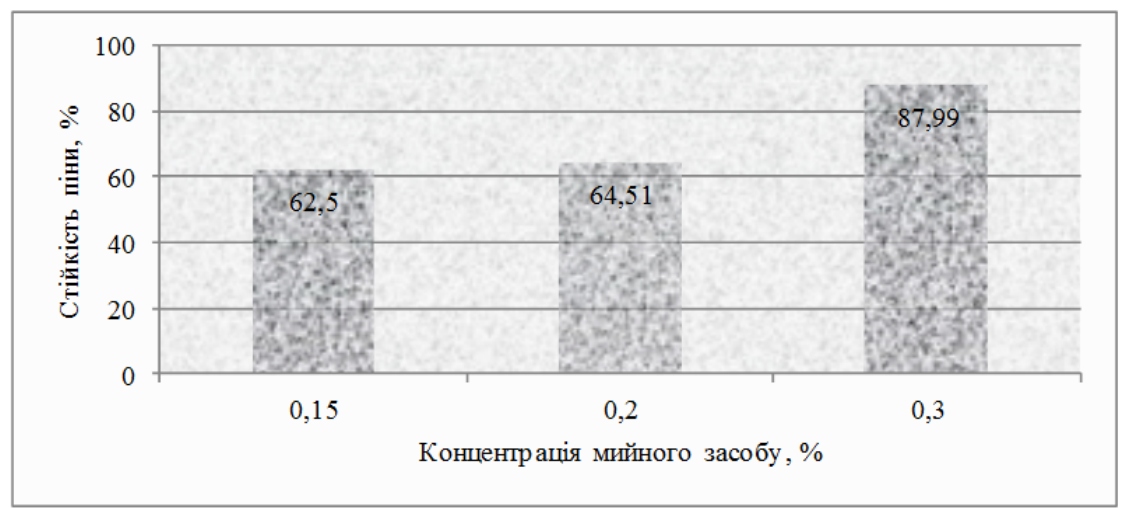

Рис. 4. Стійкість піни мийного засобу «Біомой» за температури $45{ }^{\circ} \mathrm{C}$

3 рис.4 видно, що максимальна стійкість піни засобу «Біомой» була за концентрації $0,3 \%$ і складала $87,99 \%$, що у 1,36 раза більше порівняно з концентрацією розчину $0,2 \%$ і у 1,41 раза більше порівняно 3 концентрацією $0,15 \%$. Проведеними дослідженнями встановлено, що така стійкість піни є незадовільною, оскільки, перевищує норми для мийного засобу $50 \%$.

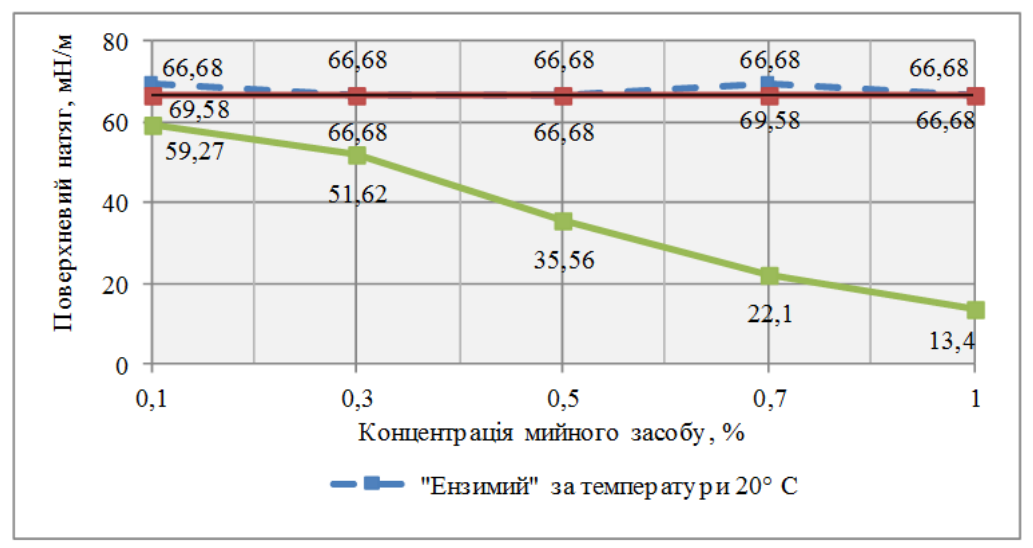

Рис. 5. Поверхневий натяг мийних засобів за температури $20^{\circ} \mathrm{C}, 45^{\circ} \mathrm{C}$ i $60^{\circ} \mathrm{C}$

Наступним етапом нашого дослідження було вивчення поверхневого натягу розчинів.

Аналіз результатів досліджень рис. 5 показав, що засіб «Ензимий» за температури $20^{\circ} \mathrm{C}$ і $60{ }^{\circ} \mathrm{C}$ проявляє майже однаковий поверхневий натяг і коливається у межах $66,68-69,58 \mathrm{mH} / \mathrm{м}$. Так, за концентрації $0,1 \%$ поверхневий натяг за температури $20{ }^{\circ} \mathrm{C}$ складає $66,68 \mathrm{mH} / \mathrm{M}$, а за температури $60{ }^{\circ} \mathrm{C}-69,58 \mathrm{mH} / \mathrm{м}$, що відповідно у 1,12 раза та у 1,17 раза більше ніж засіб «Біомой» за температури $45{ }^{\circ} \mathrm{C}$. При збільшенні концентрації до $0,3 \%$ - 0,5\%, поверхневий натяг «Ензимию» не зменшується і становить 66,68 мН/м. При цьому поверхневий натяг «Біомою» за концентрації $0,3 \%$ зменшується у 1,14 раза, за концентрації $0,5 \%-$ у 1,66 раза $(\mathrm{P} \leq 0,05)$, а за концентрації $0,7 \%$ - у 2,68 раза $(\mathrm{P} \leq 0,01)$, порівняно з $0,1 \%$ концентрацією. $1 \%$ засіб має найкращий поверхневий натяг і становить 13,4 мН/м, що свідчить про те, що поверхневий натяг розчину знижується за рахунок вмісту ПАР - сульфанолу. Вважається, чим менший поверхневий натяг, тим краща змочувальна здатність розчину і мийні властивості.

Ензимні мийні засоби використовують у CIPустановках з метою видалення білкових відкладень та мікробних біоплівок, після миття технологічного обладнання лужними і кислотними засобами.
Основною метою при створенні рідкого ензимного мийного засобу «Ензимий» було ферментативне руйнування молочно-білкових забруднень і мікробних біоплівок, тому у даному випадку значення поверхневого натягу не є суттєвим.

\section{Висновки}

Розроблений мийний засіб «Ензимий» практично не проявляе піноутворювальної здатності у концентрації від 0,03 до $1 \%$, а стійкість піни через 5 хв. не перевищує 50 \% об'єму розчину.

Поверхневий натяг $0,1 \%$ розчину «Ензимию» за температури $20^{\circ} \mathrm{C}$ i $60{ }^{\circ} \mathrm{C}$ складає 66,68 і 69,58 мН/м відповідно. При концентрації $0,3-1 \%$ поверхневий натяг за температури $20{ }^{\circ} \mathrm{C}$ і $60{ }^{\circ} \mathrm{C}$ не змінюється i складає $66,68 \mathrm{MH} / \mathrm{M}$.

Перспективи подальших досліджень. У подальшому планується вивчити вплив ензимного засобу на мікробні біоплівки, які формуються на технологічному обладнанні молокопереробних підприємств.

\section{Бібліографічні посилання}

Kyrjutkyn, G.V., Molochnykov, V.V. (1976). Mojka y dezynfekcyja tehnologycheskogo oborudovanyja 
predpryjatyj molochnoj promushlennosty. M.: Sergeev, V.N. (1989). Sanitarija i gigiena na «Pyshhevaja promushlennost'» (in Russian).

Mishhyrjak, V.G. (2012). Suchasni gigijenichni vymogy do myttja ta dezinfekcii' na harchovyh pidpryjemstvah. Donec'k (in Ukrainian).

Alagezjan, R.G. (1981). Mojushhie i dezinficirujushhie sredstva v molochnoj promyshlennosti. M.: Legkaja i pishhevaja prom (in Russian).

Degterev, G.P., Rekin, A.M. (2000). Kachestvo moloka v zavisimosti ot sanitarnogo sostojanija doil'nogo oborudovanija. Pererabotka moloka. 5, 14-17 (in Russian). predprijatijah molochnoj promyshlennosti. Leningrad: Agropromizdat (in Russian).

Kuhtyn, M.D., Perkij, Ju.B., Krushel'nec'ka, N.V. (2013). Formuvannja mikrobnyh bioplivok na poverhnjah riznyh materialiv mikroorganizmamy, jaki vydileni $\mathrm{z}$ tehnologichnogo ustatkuvannja [Tekst]. Veterynarna biotehnologija. Nizhyn: PP Lysenko M.M. 22, 292-297 (in Ukrainian).

Flint, S.H., Bremer, P.J., Brooks, J.D. (2009). Biofilms in dairy manufacturing plant-description, current concerns and methods of control. Biofouling. 11, 81-97.

Стаття надійшла до редакиії 30.09.2016 